\title{
The Impact of Intellectual Capital Efficiency in Business Reengineering: An Empirical Study on the Industrial Companies Listed on the ASE
}

\author{
Omar Fareed Shaqqour ${ }^{1}$ \\ ${ }^{1}$ Accounting Department, Faculty of Economics and Administration Sciences, Zarqa University, Jordan \\ Correspondence: Omar Fareed Shaqqour, Accounting Science Department, Zarqa University, Jordan. \\ P.O. Box 132222, Zarqa 13110, Jordan. E-mail: oshaqqour@zu.edu.jo
}

Received: November 29, 2018

Accepted: December 30, 2018

Online Published: January 29, 2019

doi:10.5539/ijbm.v14n2p187

URL: https://doi.org/10.5539/ijbm.v14n2p187

\begin{abstract}
The redesign of administrative strategic processes and polices from the root to realize the value added in the organization is called re-engineering approach, where the employees who have the knowledge, intellectual ability and skills that give them the ability to innovate and achieve the objectives of the organization, is called intellectual capital efficiency.

Knowing the importance of an intellectual capital efficiency of the company and its contribution to provide the requirements of applying re-engineering in the company and its ability to motivate the company to implement this approach, Is important and vital.

This study aims to identify the impact of intellectual capital efficiency in re-engineering on industrial firms listed on the Amman Stock Exchange ASE. To achieve this goal, the researcher measured the intellectual capital efficiency by Pulic model, and the business re-engineering through a questionnaire to measure three themes related to re-engineering, the business, extent of support the company's management to apply the business re-engineering approach, the availability of the requirements of re-engineering, and the extent of applying the reengineering approach.

The study sample consisted from 50 industrial companies listed on the ASE, during the study period (20142017), the study used SPSS and Excel to identify the descriptive characteristics of the variables of the study, and analysis the data, and it was also used regression analysis to test the hypotheses of the study.

Study results concluded that intellectual capital efficiency positively impact in supporting the company's management to apply the business re-engineering approach in the industrial companies listed on ASE, and the results also showed that the intellectual capital efficiency positively impact in the providing of the business re-engineering requirements in these companies, finally, the study finds that intellectual capital efficiency positively impact in the applying the business reengineering approach in these companies.

The study recommended to increase the interest for intellectual capital and business reengineering, and the study also recommended to increase awareness among workers in the accounting departments of the importance of the subject of intellectual capital efficiency and business reengineering.
\end{abstract}

Keywords: intellectual capital efficiency, business reengineering, industrial companies

\section{Introduction}

\subsection{Introduce to the Study}

The increasing in the size of companies, increasing in the competition between the companies, and to meet the technology changes that has occurred in the companies, found the need to update the traditional management accounting systems and methods, and replace it with modern management systems that able to develop the activities and operations of companies, and work to improve productivity, One of these methods is re-engineering.

The concept of reengineering appeared in Michael Hammer and James Chambi book, re-engineering the organization, where the authors called on all the activities of the Organization to start from the first, not just to 
restore or reform the Organization Al-Thnayan (2005). The concept of reengineering, is an approach to develop companies. It focuses on improvement from the root of strategic activities and processes that generate value added. It also focuses on organizational structures, policies and systems for organizational development, productivity improvement and customer satisfaction AlQaryuti (2000).

Re-engineering is defined by Hindonelli and Klein as the redesign of administrative strategic processes and polices from the root to realize the value added of the organization and to improve productivity and maximize business flows Obaid (2014). Paul \& Cesped (1995) defined it as the moderate variable to reach changes in the collective thought to provide the company's needs in a competitive way and achieve the target profitability.

The process of implementation of the re-engineering approach requires intellectual capital to be able to deal with the requirements of this modern approach. Mustafa (1997) considers that re-engineering is based on two critical characteristics: critical business theory and innovative thinking through the use of information technology.

The concept of reengineering is an entry point for the development of organizations. This approach focuses on the radical and fundamental change of strategic activities and processes that have added value, as well as the policies, systems and organizational structures, for the development of companies, improving productivity and achieving customer satisfaction AlQaryuti (2000).

Re-engineering is meant as a radical rethinking and fundamental redesign of activities and processes, in order to improve performance standards (cost, service, quality and speed) Dessler (2003), and it is a coherent restructuring of each organization's activities and processes, to a chive improvement for both time and cost and what is related to the goods and services provided to the client Neill (1999).

The re-engineering aims to achieve a set of objectives, including the elimination of old work routines, shift to work flexibly, reduce the costs of performance, the change from supervision of work to work through responsibilities, improve the quality of performance, and provide outstanding service Dajani (2013), and Refaee (2006) see that the objectives of re-engineering vary from company to company depending on the circumstances of each company, and these objectives vary from time to time in the company, depending on how they face a particular crisis and believes that the objectives of re-engineering in most companies is to reduce costs and reduce time and improve the quality of output.

There are several types of capital in companies, there are natural capital, physical capital, social capital and intellectual capital. Many writers have been interested in intellectual capital and have defined of what it means. Qaliati and Hassan (2010) defined it as the employees who have the knowledge, intellectual ability and skills that give them the ability to innovate and achieve the objectives of the organization, such as improving profitability and strengthening the competitive position of the organization, while Hawajra (2010) said that intellectual capital is a set of intangible assets that make the organization able to perform its functions with a competitive advantage, and makes the organization able to creative and innovate, and Burr \& Girardi (2008) has shown that intellectual capital is a set of knowledge and intangible assets owned by the organization and used by the organization to achieve and develop wealth.

Spender (1996) believes that intellectual capital is the elite of workers who have the capacity to dismantle the structure of the black box and to analyze its initial components of productive work and to re-install them in a distinct way that serves the objectives of the organization. Where Enders (1997) believes that, it is the knowledge assets that have the potential to transform technology from research to manufacturing with outstanding success. Thus, intellectual capital is concerned with two fundamental elements of the organization: the intangible assets owned by the company, in addition to its qualified employees have the ability to innovate and creativity.

The relationship between intellectual capital and re-engineering is established by the fact that re-engineering requires a shift away from the traditional work of the employee who applies the instructions automatically Al-Lozi (1999). The process of business reengineering is a continuous process, and therefore human resources management responsible is increased, because it has high skills and it able to develop new business processes Yen (1997). Where Al-Mafriji and Saleh (2003) argue that intellectual capital is the only one capable of re-engineering business, because one of its most important features is that it has diverse skills and abilities.

The aim of this research is to study the impact of intellectual capital efficiency on re-engineering in industrial firms in Jordan.

\subsection{The Study Problem}

The concept of re-engineering is one of the modern management accounting methods, this concept represents integrated approach to the organizations activities of the different types and nature, and the application of this 
concept is important to improve the competitive position of the company, and some believe that the process of re-engineering requires intellectual capital efficiency Al-Lozi (1999) and Al-Mafriji and Saleh (2003). Therefore, knowing the importance of an intellectual capital of the company and its contribution to provide the requirements of applying re-engineering in the company and its ability to motivate the company to implement this approach, Is important and vital.

The most recent research articles was studied the two variables of the study in separated way, Abd (2009), Al-Rusan and Al-Ajlunee (2010), Deeb (2009), Fathi, et al. (2013), and Jawad and Muhammad (2007), where this study try to determine the impact of the efficiency of intellectual capital in business re-engineering approach in industrial firms in Jordan.

The elements of the study problem are illustrated by answering the following questions:

1) What is the impact of the efficiency of intellectual capital in support of management for applying the re-engineering approach in industrial companies in Jordan?

2) What is the impact of the efficiency of intellectual capital in providing the requirements of the re-engineering approach in industrial companies in Jordan?

3) What is the impact of the efficiency of intellectual capital in applying the re-engineering approach in industrial companies in Jordan?

\subsection{Objectives of Study}

The study aims to know the impact of intellectual capital efficiency in supporting management for applying the re-engineering approach, providing the requirements of the re-engineering approach and

applying the re-engineering approach in industrial companies in Jordan.

\subsection{Hypotheses}

The study consists of the following hypotheses:

H1: There is a significant statistically impact of the efficiency of intellectual capital in supporting the management of applying the re-engineering approach in the industrial companies in Jordan.

$\mathrm{H} 2$ : There is a significant statistically impact of the efficiency of intellectual capital in providing the requirements of the re-engineering approach in the industrial companies in Jordan.

H3: There There is a significant statistically impact of the efficiency of intellectual capital in the application of the re-engineering approach in the industrial companies in Jordan.

\section{Theoretical Studies}

The subject of the current study is one of the modern topics that have not been studied before. Although there are many studies that have examined the subject of intellectual capital and re-engineering, however, according to the researcher's knowledge, no previous study has linked intellectual capital and re-engineering, Researcher that the study of the impact of intellectual capital in re-engineering is necessary and important.

The study Louisa (2016), which aims to find the intellectual capital dimensions (human and structural capital) role in achieving the competitive benefits of efficiency, quality, creativity and response. The study concluded that there is a relationship between intellectual capital dimensions and achieve competitive benefits in the company.

The study of Hawajra and Mohsenia (2015), which aims to determine the impact of human and social capital on performance (creative, operational and social interaction), from the point of view of managers working in Jordanian industrial companies by designing a questionnaire for the study, The study pointed out that there is an impact of human and social intellectual capital on improving the performance of business in Jordanian industrial companies, where human and social capital is of high importance, social capital has more importance than human capital, The social dimension and then the creative dimension and finally the operational dimension.

Fathi, et al. (2013) tried to analyze the relationship between intellectual capital and financial performance. The sample of the study was 49 companies registered in the financial market in Iran for the period from 2001 to 2010. The results showed that there is a positive relationship between value added working capital and value added of human capital efficiency with financial performance indicators (return on assets and return on equity).

The study Kong (2010) aimed to determine the impact of intellectual capital by measuring human capital, structural capital, and relative capital in innovation in the company, especially in social institutions. The results of the study showed that institutions can benefit from the concept of intellectual capital as an administrative strategy that will help social and creative institutions. 
Study Deep (2009), the study aimed at evaluating the opportunities for applying the process reengineering approach to improve the competitiveness of pharmaceutical companies in Aleppo. The results of the study showed that it is possible to implement the process reengineering approach by supporting the senior management and the availability of suitable human resources and the availability of advanced information technology

Finally, the study Abd (2009), aimed to identify the impact of intellectual capital in the application of TQM at the University of Tikrit, where the results of the study showed a relationship between intellectual capital and the possibility of applying TQM, the study also found a statistically significant relationship between the dimensions of intellectual capital and the possibility of applying TQM.

\section{Study Methods}

\subsection{Population and Sample}

The social of the study consists of all industrial companies listed on ASE for the year 2017, but the sample of study, but the sample of the study contains of 50 industrial companies was chosen randomly, and the researcher distributed a questionnaire to each of the quality manager, the quality supervisor, the production manager and the financial manager of each company, 200 questionnaires were distributed, but 162 questionnaires were collected valid and were analyzed by statistical.

The characteristics of the study sample members:

Table 1. Characteristics of the study sample

\begin{tabular}{lll}
\hline Scientific qualification & Number & Percentage \\
\hline Diploma Community College & & \\
Bachelor & & \\
Post Graduate & Number & Percentage \\
Job Title & & \\
Quality Manager & \\
Quality Monitor & \\
Production Manager & \\
Financial manager & \\
\hline
\end{tabular}

\subsection{Sources of Data Collection}

The study was based on the data of the annual reports of industrial companies in Jordan to measure the intellectual capital efficiency of these companies, and also the study was based on a questionnaire prepared by researcher for industrial companies in Jordan to measure the dependents variable

\subsection{Measure Variables of Study}

The study variables consist of three dependent variables and one independent variable:

The study variables consist of three dependent variables and a dependent variable:

(1) Dependent variables:

1. The extent of management support to apply the business reengineering approach: It was measured by questions (1-7)

2. The extent of providing of the requirements of the business reengineering approach: It was measured by questions (8-14)

3. The extent of application of business reengineering approach: It was measured by questions (15-23)

(2) Independent variable: the efficiency of intellectual capital

The efficiency of the company's intellectual capital was measured by the model Pulic (2006) \& Pulic (1998).

$$
\begin{gathered}
\mathrm{VAIC}=\mathrm{HCE}+\mathrm{SCE}+\mathrm{CEE} \\
\mathrm{VAIC}=(\mathrm{VA} / \mathrm{HC})+(\mathrm{VA}-\mathrm{HC} / \mathrm{VA})+(\mathrm{VA} / \mathrm{BV})
\end{gathered}
$$

Where:

VAICValue added of intellectual capital.

HCE: Human Capital Efficiency. 
SCE: Structural Capital Efficiency.

CEE: Working capital efficiency

VA: Net operating income + salaries expenses + depreciation and amortization expenses

HC: Salaries expenses

BV: Book value of tangible assets

\subsection{Statistical Methods}

The researcher used the SPSS program to analyze the study data collected from the financial statements of the companies and from the questionnaire to test hypotheses and achieve the objectives of the study. The statistical methods include the Cronbach-Alpha test, the frequencies, the averages, standard deviations and the simple regression.

\subsection{Test the Stability and Validity Of The Tool}

In order to ensure that there is an internal consistency in the questions of the questionnaire and to verify their stability, the Cronbach-Alpha test was used.

When the Kron Bach Alpha coefficient was applied for the questionnaire of the study, the result of the alpha coefficient value was 0.951 , which shows that there is a high degree of consistency for all questions.

Table 2 shows the results of the application of the alpha coefficient to the study questions.

Table 2. Results of applying alpha coefficients to the study questions

\begin{tabular}{lll}
\hline Variable & Questions & Alpha Factor \\
\hline All questions & $1-23$ & 0.951 \\
Extent of management support & $1-7$ & 0.834 \\
Extent of Availability of requirements & $8-14$ & 0.891 \\
Extent of application & $15-23$ & 0.931 \\
\hline
\end{tabular}

\section{The Results}

SPSS and EXCEL were used to analyze the study data and to identify the descriptive characteristics of the dependent and independent study variables and the results of the hypothesis test. Table (3) presents the descriptive statistics of the variables of the study. Each hypothesis and descriptive statistics of their variables show in table 3 and table 4 :

4.1 Statistics of the Variables of the Study

Table 3. Descriptive statistics of the variables of the study

\begin{tabular}{llllll}
\hline & $\mathrm{N}$ & $\mathrm{Min}$ & Max & Mean & Std. Dev. \\
\hline Intellectual capital efficiency & 162 & -10.6 & 4.92 & 5.2517 \\
Extent of management support & 162 & 2.43 & 4.29 & 3.55 & 0.6308 \\
Extent of availability of requirements & 162 & 2.86 & 4.57 & 3.585 & 0.6919 \\
Extent of application & 162 & 1.89 & 4.56 & 3.277 \\
\hline
\end{tabular}

\subsection{Test the Hypotheses and Discuss the Results}

Table 4. Regression analysis of study hypothesizes

\begin{tabular}{|c|c|c|c|c|c|}
\hline Hypothesis & $\mathrm{T}$ & $\mathrm{F}$ & T sig & Result of $\mathrm{HO}$ & Result of H1 \\
\hline HO 1 & 9.991 & 99.82 & 0.000 & rejected & accepted \\
\hline HO 2 & 2.032 & 4.130 & 0.044 & rejected & accepted \\
\hline $\mathrm{HO} 3$ & 4.422 & 6.604 & 0.011 & rejected & accepted \\
\hline
\end{tabular}


HO1: There is no statistically significant impact of the efficiency of intellectual capital in supporting the management of the re-engineering approach in the industrial companies in Jordan.

The company's intellectual capital efficiency was measured by Pulic (2006) and Pulic (1998), where the extent of supporting management of applying the concept of re-engineering was measured by questions 1 to 7 in the questionnaire.

Table 4 shows the results of the test of the impact of intellectual capital efficiency in increasing the support of the management for the re-engineering approach in the industrial companies in Jordan, where the value of P-value sig. $=0.00$, which is less than the significant level $\alpha=0.05$, thus rejecting the null hypothesis and accepting the alternative hypothesis, that is, the efficiency of intellectual capital impacts on support of management to the re-engineering approach in industrial companies in Jordan.

HO2: There is no statistically significant impact of the efficiency of intellectual capital in providing the requirements of the re-engineering approach in the industrial companies in Jordan.

The company's intellectual capital efficiency was measured by Pulic (2006) and Pulic (1998), where the extent of providing the requirements of the re-engineering approach was measured by questions 8 to 14 in the questionnaire.

Table 4 shows the results of the test of the impact of intellectual capital efficiency in providing the requirements of the re-engineering approach in the industrial companies in Jordan, where the value of P-value sig. $=0.044$, which is less than the significant level $\alpha=0.05$, thus rejecting the null hypothesis and accepting the alternative hypothesis, that is, the efficiency of intellectual capital impacts on providing the requirements of the re-engineering approach in industrial companies in Jordan.

HO3: There is no statistically significant impact of the efficiency of intellectual capital in the application of the re-engineering approach in the industrial companies in Jordan.

The company's intellectual capital efficiency was measured by Pulic (2006) and Pulic (1998), where the extent of the application of the re-engineering approach was measured by questions 15 to 23 in the questionnaire.

Table 4 shows the results of the test of the impact of intellectual capital efficiency in the application of the re-engineering approach in the industrial companies in Jordan, where the value of P-value sig. $=0.11$, which is less than the significant level $\alpha=0.05$, thus rejecting the null hypothesis and accepting the alternative hypothesis, that is, the efficiency of intellectual capital impacts on the application of the re-engineering approach in industrial companies in Jordan.

\section{Conclusions and Recommendations}

\subsection{Conclusions}

The study reached the following results:

1- The results of the study found that the efficiency of intellectual capital positively impacts on the support of the management for the re-engineering approach in the industrial companies in Jordan. The existence of workers and employees with high abilities and have ability to innovate, make them more capable to improve and develop the company. Fathi, et al. (2013) showed that there is a positive relationship between intellectual capital and financial performance indicators (return on assets, return on equity and revenue growth), as well as the study of Jawad and Muhammad (2007) found that the relations between elements of intellectual capital and organizational creativity are strong, The results show that management at various levels supports the development and application of modern concepts and approaches in management accounting, as business re-engineering.

2- The results of the study showed that the efficiency of intellectual capital positively impacts the provision of the requirements of the re-engineering approach in the industrial companies in Jordan. The existence of workers and employees with high abilities and have the ability to create and innovate is the most important requirement for the development of the company. This result is consistent with the study of Louisa (2016), which found that intellectual capital contributes to achieve the competitive advantage.

3. The study concluded that the efficiency of intellectual capital positively impacts in the application of the re-engineering approach in the industrial companies in Jordan. This is in line with the study of Abd (2009). The results showed that there is a relationship between intellectual capital measures and the extent of applying TQM. 


\subsection{Recommendations}

Finally, the following recommendations are proposed:

1. Optimistic and positive results reached, it is supposed to support and promote and increase attention to the variables of intellectual capital and re - engineering.

2. The need to research and expand the society of the study to include other sectors in subsequent studies, so as not only to industrial companies in Jordan, but beyond other sectors in Jordan and other countries to include (financial sector, universities, hospitals, insurance, telecommunications and other sectors).

3. Increase awareness and understanding among employees in the financial departments and accounting sections of the importance of the subject of intellectual capital efficiency and re-engineering.

\section{References}

Abd, G. (2009). The Impact of Intellectual Capital on the Application of Total Quality Management (TQM), A Survey Study at Tikrit University. Tikrit Journal of Administrative and Economic Sciences, 5(15).

Al-Lozi, S. (1999). Organizational Development Basics and Modern Concepts. Dar Wael Publishing, Amman, Jordan.

Al-Mafriji, A., \& Saleh, A. (2003), Intellectual Capital, Publications of the Arab Organization for Administrative Development. Cairo.

Al-Qariouti, M. K. (2000). Organizational Behavior. Dar Al Shorouq, Jordan, Amman.

Al-Rusan, \& AlAjlunee (2010). The Impact of Intellectual Capital on Creativity in Jordanian Banks, Damascus University. Journal of Economic and Legal Sciences, 26(2).

Al-Thnayan, K. (2005). Management Reengineering, Al-Riyadh Daily Newspaper.

Burr, R., \& Girard, A. (2008). Intellectual Capital: More than the Interaction of Competence x commitment, Australian Journal of Management, 27.

Dajani, I. (2013). Proposed Model for Reengineering and Computerizing Administrative Processes in Higher Education Institutions. Damascus University Journal, 29(1).

Deeb, S. (2009). Evaluating Opportunities for Implementing Process Reengineering as an Approach to Improving Competitiveness: A Field Study on Pharmaceutical Industry Companies in Halab. Tishreen University Journal for Research and Scientific Studies, 31(1).

Endres, A. (1997). Improve R. \& D. performance the juran way. John Willey \& sons.

Fathi, S., Farahmand, S., \& Khorasani, M. (2013). Impact of Intellectual Capital on Financial Performance. International Journal of Academic Research in Economics and Management Sciences

Hawajra, K. (2010). Studying the Linkage of Capital Investment Strategies to the Competitive Performance of Institutions. Journal of the University of Sharjah for Humanities and Social Sciences, 7(2).

Hawajra, K., \& Almahasnh, M. (2015). The Impact of Intellectual Capital (Human and Social) on Business Performance. Dirasat Journal, 42(1).

Jawad, A., \& Muhammad, K. (2007). The Impact of Intellectual Capital on Organizational Creativity, Analytical Study at the University of Babl. Journal of Ahlu lbait University. Retrieved from http://www.ahlulbaitonline.com/karbala/New/html/ search / research.php? ID = 30

Kong, E. (2010). Analyzing BSC and IC's usefulness in nonprofit societies. Journal of Intellectual Capital.

Louisa, F. (2016). The Role of Intellectual Capital in Achieving the Competitive Advantage, unpublished $\mathrm{PhD}$ thesis, University of Mohamed Khader, Algeria.

Mustafa, A. (1996). Reconstruction as a Competitive Entrance, Management News, Issue 16.

Neill, P., \& Sohal, A. S. (1999). Business Process Reengineering A review of recent literature. Technovation, 19(9), 571-581.

Obeid, S. (2014). Impact of Intellectual Capital Investment on Total Quality Management (Applied Study on Customs Affairs in the Kingdom of Bahrain). Unpublished Master Thesis, Applied Science University, Bahrain.

Paul, A., \& Cespedes, S. (1995). Reengineering is just a catalyst in bank culture change. Bankers Magazine, 178(3), 46-52. 
Pulic, A. (1998). 'Measuring the Performance of Intellectual Capital in Knowledge Economy.

Pulic, A. (2006). VAICTM-An Accounting Tool For IC Management (on-line).

Qaliati, S., Hassan, A. (2010). Strategic Planning for the Development of Intellectual Capital in Institutions. Intellectual Capital Development Conference, Kuwait.

Refaee, M. (2006). Process Reengineering (1st ed.). Cairo: Ain Shams University.

\section{Copyrights}

Copyright for this article is retained by the author(s), with first publication rights granted to the journal.

This is an open-access article distributed under the terms and conditions of the Creative Commons Attribution license (http://creativecommons.org/licenses/by/4.0/). 